fournal of Medical Genetics (1975). 12, 217.

\title{
Attitudes of patients and their relatives to Huntington's disease
}

\author{
ROBERT STERN and ROSWELL ELDRIDGE* \\ From the Section on Genetics in Epidemiology, Epidemiology Branch, Collaborative and Field Research, National \\ Institute of Neurological Diseases and Stroke, Bethesda, Maryland 20014, USA
}

\begin{abstract}
Summary. Reaction to medical, social, and genetic implications of Huntington's disease was evaluated by means of a questionnaire mailed to members of a lay organization concerned with this disease in the United States. One thousand and sixty-five of the approximately 2600 members chose to respond.

Patients and those at high risk found physical disabilities most disturbing while mental deterioration and personality change were the most disturbing to spouses of patients.

The best source of information regarding the disease for $46 \%$ was the lay organization itself. Medical specialists or genetic counsellors were cited as the best source of information by $18 \%$. The transmission risk in Huntington's disease was correctly stated to be one-half by $92 \%$ of all respondents including $94 \%$ of those who indicated the lay organization as best source and $91 \%$ of those who indicated medical specialists and genetic counsellors as best source.

If at risk for Huntington's disease, $86 \%$ of respondents would modify their family size; desire for limitation was greatest among those affected but lowest among young adults at high risk. If a screening test were available, $23 \%$ at high risk might refuse it.
\end{abstract}

Increased knowledge of human genetics has generated interest in its practical application in the form of genetic counselling. As experience with counselling accumulates, a number of issues have emerged worthy of discussion and study. Simply stated these include the questions: who should be counselled? what should be the content and thrust of the counsel ? and who should do the counselling ?

There is general agreement that an important group to counsel includes those with simply inherited 'burdensome' traits because of the relatively high risk to offspring and cost to society (Emery and Smith, 1970; Smith et al, 1971). But this in turn raises the question as to what are 'burdensome' traits.

What is the proper objective of genetic counsel-

Received 14 October 1974.

* Reprint requests to: R. E., Section on Genetics in Epidemiology, NINCDS, NIH, Bldg. 31, Rm. 801-34, Bethesda, Maryland 20014 , USA ling ? If genetic counselling is regarded as a form of preventive medicine (McKusick, 1969; Smith et al, 1971; Hecht and Holmes, 1972) there is an obligation to seek families with 'burdensome' genetic disorders and advise their members to limit or avoid childbearing. But how does one proceed to ascertain, contact, and influence high risk patients and their relatives while respecting the privacy of individual family members, the confidentiality of their information, and their own role in planning their family?

Who should counsel ? What is appropriate training for counsellors and what should be their relationship to the individuals counselled? Is a family physician of long acquaintance more effective than a highly trained medical geneticist who is visited on one or two occasions ?

One may look at these questions from another perspective. How many in need of genetic counsel actually seek advice? What advice do they seek ? From whom do they seek it? 
We recently had the opportunity to evaluate some of these issues as they apply to Huntington's disease, a trait which is of particular interest for study. Huntington's disease is inherited as an autosomal dominant trait with relatively uniform expression. Dementia, personality change, and movement disorder usually develop insidiously in those carrying the gene sometime between the ages of 25 and 50 years and progress to death over 10 to 15 years (Waters, 1848; Huntington, 1872; Bruyn, 1968). Because of these features it is regarded by physicians as particularly burdensome (Murphy, 1973).

In 1958, the frequency of heterozygotes for the Huntington disease gene in Michigan was calculated to be $1.01 / 10000$ by Reed and Neel (1959). If this frequency obtains over the entire United States there are some 20000 individuals now living in the country who have or will develop Huntington's disease. Of added significance is that those affected may have an increased rate of fertility (Wallace and Parker, 1973). Finally, there are now several procedures which may ultimately permit determination of presymptomatic carriers (Klawans et al, 1972; Menkes and Stein, 1973).

\section{Materials and methods}

Questionnaires were sent through the Committee to Combat Huntington's Disease (CCHD) to approximately 2600 families with one or more members said to have Huntington's disease. CCHD is a voluntary lay organization, with a Medical Advisory Board, established in 1967 to foster interest and research in Huntington's disease and provide support and counsel to affected families.

Through the questionnaire information or attitudes were sought on the following eight points from each respondent: (1) relationship to those in the family with Huntington's disease; (2) length of the disease in closest relative; (3) most disturbing feature of Huntington's disease; (4) best source of information regarding Huntington's disease; (5) risk to offspring of a parent with Huntington's disease; (6) information desired for family planning; (7) attitude towards a simple predictive test, and (8) influence, if any, upon plans for childbearing of one learned he or she carried the gene for Huntington's disease.

Questions relating to items 3, 4, and 6 were phrased so that responses were open-ended. Two independent observers placed responses to these questions in discrete categories and scored them. When disagreement between the two observers occurred, a third observer performed the final scoring independently.

To test the significance of association between pairs of variables all were considered discrete, the appropriate contingency table was constructed, and the chi square calculated. For construction of the contingency table and performance of tests of significance, the SBC Call 360 SCHISQ2 program was utilized.*

\section{Results}

Two months after the mailing to approximately 2600 families belonging to CCHD 1065 questionnaires had been completed adequately and returned to us. These served as the basis for this report.

Respondents lived in each of the American States with the exception of New Hampshire and Tennessee and there seemed no geographical bias. Seventyone percent of the respondents were female, $26 \%$ were male, and for $3 \%$ the sex was unstated. Forty-three percent were 15 to 39 years of age, $45 \%$ were older, and $12 \%$ did not state their age. Thirtyseven of the 1065 respondents indicated they had Huntington's disease, 241 indicated they were married to an affected individual, another 403 were considered to be at high risk since they were age 45 or under and indicated they had an affected parent, 227 were at lesser risk, and for 11 others the degree of risk could not be determined. The remaining 146 were not directly at risk. There were from one to 12 individuals affected in each family. In $81 \%$ of the families there were at least two affected.

The closest relative had been symptomatic for more than five years in four out of five families and for more than 10 years in over half the families.

Disturbing feature. Responses regarding the most disturbing features of Huntington disease were placed in one of four categories: mental disturbance (consisting generally of personality change or dementia); physical disturbance (disordered movement, speech, eating or swallowing); social disturbance (generally embarrassment to the family, financial burden, or profound change in roles); and genetic concern (generally anxiety regarding genetic status with onset of symptoms during or after childbearing age).

A physical disturbance was listed as most disturbing by $44 \%$; mental disturbance by $29 \%$; social disturbance by $6 \%$; genetic concern by $8 \%$, and some other by $13 \%$. In Table I the most disturbing feature is listed according to the risk of the respondent for Huntington's disease. The physical aspects of Huntington's disease were more often most distressing to those actually affected and those at various risk. Mental changes were most often distressing to spouses of those actually affected or at high risk. Further analysis indicated those whose

* Office of Biometry, NINDS, National Institutes of Health, Bethesda, Maryland 20014, USA. 
TABLE I

MOST DISTURBING FEATURE ACCORDING TO RISK OF RESPONDENT FOR HUNTINGTON'S DISEASE

\begin{tabular}{|c|c|c|c|c|c|}
\hline \multirow{2}{*}{ Risk } & \multicolumn{5}{|c|}{ Disturbing Feature } \\
\hline & Mental & Physical & Social & Genetic & Other \\
\hline Affected $(n=37)$ & $7(19 \%)$ & $22(60 \%)$ & $2(5 \%)$ & $2(5 \%)$ & $4(11 \%)$ \\
\hline $\begin{array}{l}\text { At risk } \\
\text { High }(\mathrm{n}=403) \\
\text { Low }(\mathrm{n}=227) \\
\text { Uncertain }(\mathrm{n}=11)\end{array}$ & $\begin{array}{r}108(27 \%) \\
38(17 \%) \\
2(18 \%)\end{array}$ & $\begin{array}{r}191(47 \%) \\
112(49 \%) \\
7(64 \%)\end{array}$ & $\begin{array}{l}23(6 \%) \\
13(6 \%) \\
0\end{array}$ & $\begin{array}{l}35(9 \%) \\
22(10 \%) \\
0\end{array}$ & $\begin{array}{r}46(11 \%) \\
42(18 \%) \\
2(18 \%)\end{array}$ \\
\hline $\begin{array}{l}\text { No risk } \\
\text { Spouse of affected }(n=241) \\
\text { Other }(n=146)\end{array}$ & $\begin{array}{r}100(42 \%) \\
53(36 \%)\end{array}$ & $\begin{array}{l}83(34 \%) \\
54(37 \%)\end{array}$ & $\begin{array}{r}13(5 \%) \\
8(6 \%)\end{array}$ & $\begin{array}{l}17(7 \%) \\
10(7 \%)\end{array}$ & $\begin{array}{l}28(12 \%) \\
21(14 \%)\end{array}$ \\
\hline $\begin{array}{l}\text { Total }(n=1065) \\
\text { Average }\end{array}$ & $308(29 \%)$ & $469(44 \%)$ & $65(6 \%)$ & $86(8 \%)$ & $143(13 \%)$ \\
\hline
\end{tabular}

Mental changes more often disturbing to spouses while physical changes more often disturbing to those at risk, $P \leqslant 0.01$.

nearest relative had been affected less than five years were most concerned with mental changes while those with a longer association were concerned about physical changes. Economic burden and change in family structure were mentioned increasingly as the duration of illness in relatives increased. Genetic aspects of the disease were mentioned as being most disturbing by no more than $10 \%$ of any group.

Source of information. Sixty-four percent of respondents listed one best source, $32 \%$ indicated two best sources, and $49 \%$ listed three of more best sources. Table II lists the first mentioned best source according to the risk of the respondent. Note that CCHD was listed most frequently and was considered the best source by all groups except for spouses of those affected. The medical sources indicated by $28 \%$ of respondents consisted of: family physicians, $10 \%$; neurologists or other specialists, $15 \%$; and genetic counsellors, $3 \%$. Thus, among all respondents less than one in 30 indicated a genetic counsellor as best source.

Knowledge of risk. The risk of an affected individual transmitting the gene for Huntington's disease to each offspring was correctly stated to be half by $92 \%$ of all respondents. Those correct included $94 \%$ of those indicating CCHD as their best source of information; $92 \%$ of those listing relatives as the best source; $91 \%$ listing family physicians, and $82 \%$ listing other sources such as personal library research. There was no correlation between the number of affected in a respondent's family and his or her knowledge of the risk.

Information desired. Six hundred and fiftynine respondents gave a specific response to the question: 'If there were a chance you and your

TABLE II

BEST SOURCE OF INFORMATION ACCORDING TO RISK OF RESPONDENT FOR HUNTINGTON'S DISEASE

\begin{tabular}{|c|c|c|c|c|}
\hline \multirow{2}{*}{ Risk } & \multicolumn{4}{|c|}{ Best Source of Information } \\
\hline & Relative & Medical & CCHD & Other \\
\hline Affected $(n=37)$ & $9(24 \%)$ & $11(30 \%)$ & $13(35 \%)$ & $4(11 \%)$ \\
\hline $\begin{array}{l}\text { At risk } \\
\text { High }(\mathrm{n}=403) \\
\text { Low }(\mathrm{n}=227) \\
\text { Uncertain }(\mathrm{n}=11) \\
\end{array}$ & $\begin{array}{r}65(16 \%) \\
50(22 \%) \\
2(18 \%) \\
\end{array}$ & $\begin{array}{r}98(24 \%) \\
52(23 \%) \\
3(27 \%) \\
\end{array}$ & $\begin{array}{r}214(53 \%) \\
95(42 \%) \\
5(46 \%) \\
\end{array}$ & $\begin{array}{c}26(7 \%) \\
30(13 \%) \\
1(9 \%) \\
\end{array}$ \\
\hline $\begin{array}{l}\text { No risk } \\
\text { Spouse of affected }(n=241) \\
\text { Other }(n=146)\end{array}$ & $\begin{array}{l}17(7 \%) \\
20(3 \%)\end{array}$ & $\begin{array}{l}99(41 \%) \\
36(25 \%)\end{array}$ & $\begin{array}{l}93(39 \%) \\
67(46 \%)\end{array}$ & $\begin{array}{l}32(13 \%) \\
23(16 \%)\end{array}$ \\
\hline $\begin{array}{l}\text { Total }(n=1065) \\
\text { Average }\end{array}$ & $163(15 \%)$ & $299(28 \%)$ & $487(46 \%)$ & $116(11 \%)$ \\
\hline
\end{tabular}

CCHD listed as single best source by $46 \%$ of all respondents; spouses less likely to list relatives as best source than those at risk, $P \leqslant 0.01$. 
TABLE III

INFORMATION DESIRED ACCORDING TO RISK OF RESPONDENT FOR HUNTINGTON'S DISEASE

\begin{tabular}{|c|c|c|c|c|}
\hline & \multicolumn{4}{|c|}{ Response } \\
\hline & $\begin{array}{l}\text { Do not want } \\
\text { Children }\end{array}$ & $\begin{array}{l}\text { Risk and } \\
\text { Predictive } \\
\text { Test }\end{array}$ & $\begin{array}{l}\text { Nature and } \\
\text { Treatment of } \\
\text { HD }\end{array}$ & $\begin{array}{l}\text { Don't want } \\
\text { more } \\
\text { Information }\end{array}$ \\
\hline Affected $(n=18)$ & $10(56 \%)$ & $4(21 \%)$ & $3(17 \%)$ & $1(6 \%)$ \\
\hline $\begin{array}{l}\text { At risk } \\
\text { High }(n=262) \\
\text { Low }(n=137) \\
\text { Uncertain }(n=4)\end{array}$ & $\begin{array}{l}54(21 \%) \\
31(23 \%) \\
2(50 \%)\end{array}$ & $\begin{array}{c}140(53 \%) \\
81(59 \%) \\
-\end{array}$ & $\begin{array}{l}49(19 \%) \\
17(12 \%) \\
1(25 \%)\end{array}$ & $\begin{array}{l}19(7 \%) \\
8(6 \%) \\
1(25 \%)\end{array}$ \\
\hline $\begin{array}{l}\text { No risk } \\
\text { Spouse of affected }(n=143) \\
\text { Other }(n=95)\end{array}$ & $\begin{array}{l}52(36 \%) \\
31(33 \%)\end{array}$ & $\begin{array}{l}64(45 \%) \\
48(50 \%)\end{array}$ & $\begin{array}{l}21(15 \%) \\
11(12 \%)\end{array}$ & $\begin{array}{l}6(4 \%) \\
5(5 \%)\end{array}$ \\
\hline $\begin{array}{l}\text { Total }(n=659) \\
\text { Average }\end{array}$ & $180(27 \%)$ & $337(51 \%)$ & $102(16 \%)$ & $40(6 \%)$ \\
\hline
\end{tabular}

Affected most likely to respond they simply would not want children if at risk while those at high risk least likely to make this response, $P \leqslant 0.025$.

spouse had Huntington's disease what information would you want in order to decide about having children ?' The remaining 416 respondents did not provide useful answers, generally because they had already completed their families. Table III gives the type of information desired by the 659 respondents according to their risk for Huntington's disease. Note that of those affected, most indicated they would not have children but those at high risk were interested in risk figures and availability of a predictive test while spouses were likely to make either response.

Influence of family planning. Eighty-two percent of the respondents indicated that knowing they carried the gene for Huntington disease would influence the number of children planned. Of 903 commenting specifically, $85 \%$ want no children, $15 \%$ would want fewer children, and one individual would want more children. Among the 350 respondents aged between 15 and $34,70(20 \%)$ said they might not be influenced compared with 34 $(11 \%)$ of the 310 between 34 and 49 years.

Table IV indicates the influence upon number of children planned according to the respondents' best source of information. Eighty-seven percent of those indicating medical specialists and genetic counsellors as best source and $84 \%$ of those indicating CCHD as their best source would be influenced while $78 \%$ of those indicating other sources would be influenced. Response to this question was not correlated with sex, most disturbing feature, number of affected in family, or length of exposure.

Eighty-one percent of those affected with Huntington's disease would have altered their childbearing plans if they had known they carried the gene. Among spouses of affected who commented $90 \%$

TABLE IV

INFLUENCE UPON NUMBER OF CHILDREN ACCORDING TO SOURCE OF INFORMATION

\begin{tabular}{|c|c|c|c|c|}
\hline Source & Influenced & Not-influenced & Maybe & Not Given \\
\hline Relative $(n=163)$ & $127(78 \%)$ & $9(6 \%)$ & $22(13 \%)$ & $5(3 \%)$ \\
\hline Family doctor $(n=121)$ & $94(78 \%)$ & $6(5 \%)$ & $17(14 \%)$ & $4(3 \%)$ \\
\hline $\begin{array}{l}\text { Medical specialists and genetic } \\
\text { counsellors }(n=178)\end{array}$ & $155(87 \%)$ & $1(1 \%)$ & $14(8 \%)$ & $8(4 \%)$ \\
\hline CCHD (n=487) & $408(84 \%)$ & $20(4 \%)$ & $42(9 \%)$ & $17(3 \%)$ \\
\hline Other $(n=116)$ & $91(78 \%)$ & $6(5 \%)$ & $9(8 \%)$ & $10(9 \%)$ \\
\hline $\begin{array}{l}\text { Total }(n=1065) \\
\text { Average }\end{array}$ & $875(82 \%)$ & $42(4 \%)$ & $104(10 \%)$ & $44(4 \%)$ \\
\hline
\end{tabular}


TABLE V

\begin{tabular}{|c|c|c|c|}
\hline & Want Test & Do not want Test & Uncertain \\
\hline Affected $(n=31)$ & $29(94 \%)$ & - & $2(6 \%)$ \\
\hline $\begin{array}{l}4 t \text { risk } \\
\text { High }(n=339) \\
\text { Low }(n=220) \\
\text { Uncertain }(n=11)\end{array}$ & $\begin{array}{c}307(77 \%) \\
189(86 \%) \\
9(82 \%)\end{array}$ & $\begin{array}{r}24(6 \%) \\
7(3 \%) \\
1(9 \%)\end{array}$ & $\begin{array}{c}68(17 \%) \\
24(11 \%) \\
1(9 \%)\end{array}$ \\
\hline No risk $(n=365)$ & $281(77 \%)$ & $22(6 \%)$ & $62(17 \%)$ \\
\hline $\begin{array}{l}\text { Total }(n=1026) \\
\text { Average }\end{array}$ & $815(80 \%)$ & $54(5 \%)$ & $157(15 \%)$ \\
\hline
\end{tabular}

Those at high risk indicate less desire for test than those at low risk, $P \leqslant 0.05$.

would have no children, $2 \%$ would not be influenced, and $8 \%$ were uncertain.

Information desired for childbearing. In Table $\mathrm{V}$ the attitudes among 1026 respondents towards a simple predictive test according to their risk for Huntington's disease are listed. Although $94 \%$ of those affected said they would have wanted such a test only $80 \%$ of all respondents would. Note that among those at high risk and for whom a predictive test would be most applicable almost one-quarter either did not want the information or were equivocal. Men were more positive about the test than women. Source of information, age of respondent, number of family members affected, and length of illness in nearest relative were not factors.

\section{Discussion}

Huntington's disease often evokes strong reaction among physicians and geneticists familiar with its features, many of whom regard it among the most 'burdensome' of hereditary traits (Murphy, 1973). But the view of the patients themselves and their relatives should also be instructive to those who provide their care and counsel.

As indicated, respondents in this study were most disturbed by the physical and mental aspects of Huntington's disease rather than the social or genetic. Those affected or at high risk were most concerned by physical symptoms such as chorea, ataxia, and eating difficulties. Their spouses, in contrast, were more distressed by psychological features such as dementia and change of personality. Spouses commented particularly upon the emotional and psychological suffering resulting from premature and erratic physical and mental deterioration in their mates. Most devastating was such deterioration over months of years accompanied nonetheless by the birth of one or more children only after which was there the revelation of a family history of Huntington's disease.

In addition to these views concerning the burden of Huntington's disease it would be desirable to have a more quantitative measure of this personal burden and some idea of the cost to society at large. Bearing on the latter is a recent Australian study by Wallace in 1973. Among 181 patients with Huntington's disease in Queensland, $27 \%$ required confinement in a mental institution, $7 \%$ were cared for in chronic care institutions, and the remainder were working, being cared for at home, or had died without being institutionalized. In contrast, in a British series, 80 of 102 patients followed over a 16-year period were eventually admitted to mental hospitals (Dewhurst et al, 1970). Also noteworthy in the Queensland study were a high car accident rate among affected men and a higher fertility rate among affected women due apparently to a few who continued having children despite the presence of symptoms.

Counselling in HD. A number of studies have dealt with the impact of counselling received by those counselled at genetics clinics (Carter et al, 1971; Sibinga and Friedman, 1971; Leonard et al, 1972) but many of those in need are not seen at such clinics (Emery and Smith, 1970). It was from the broader population of those in need of counsel but not necessarily seen in a formal genetics clinic that our sample was drawn.

All respondents were ascertained through membership in the Committee to Combat Huntington's Disease, a voluntary lay organization requiring no dues and which, at the time the study was undertaken in 1972, was composed of 15 regional chapters representing approximately 2600 individual families.* Although we did not verify the diagnosis of

* By September 1974 more than 49 regional chapters were operat- 
Huntington's disease in any case each chapter has one or more physician consultant and most respondents mentioned contact with a variety of medical consultants. Nevertheless, the highly select nature of the respondent sample requires emphasis; the respondents considered themselves affected with Huntington's disease or were related to someone who did; were already self-selected members of the CCHD; and finally, respondents elected to fill out and send in the questionnaire.

Just as the burden of Huntington's disease was viewed distinctively by those at high risk the type of information requested and reaction to a screening test by this group also differed. Those at high risk were most interested in the chances of a successful treatment or cure in contrast to other risk groups who were more interested in predictive testing. Approximately 1 out of 4 at high risk for Huntington's disease was not prepared to take a predictive test. Others have commented that a sizeable number of those at high risk for a serious genetic disease would choose not to know their status (Lappe et al, 1972; Lederberg, 1973). The implication of a predictive and screening test for a dominant disorder differs from that for a recessive disorder, especially when the onset of the dominant disorder may be relatively late in life and symptoms become incapacitating. When screened for a recessive disorder such as Tay-Sachs disease the parents' concern is chiefly with the unlikely possibility that a future child will be affected. In contrast, a parent at risk for Huntington's disease who is screened has the immediate prospect of learning he or she is destined for a premature death following a protracted illness, and that each child has a $50 \%$ chance of the same fate.

A number of procedures now under study may, with time, permit detection of those presymptomatic for Huntington's disease. These include one based on response to L-dopa and another based on replicative life span of cultured skin fibroblasts (Klawans et al, 1972; Menkes and Stein, 1973). One day, prenatal detection may be possible, but those at risk for the disease who do not want to know their status may well not be interested because of the implication for themselves.

Among the 146 respondents who would either refuse or question a screening test, 13 indicated that risk for the disease would not alter their childbearing plans and 27 others were uncertain. This is consistent with the practical experience of one genetics clinic in which 10 of 57 couples deliberately chose to have more children although they had been informed the risk any child would be affected with a serious genetic disorder was greater than $10 \%$
(Emery et al, 1973). Individuals opting for neither screening test nor family limitation may be motivated by several factors. These may include the belief that uncertainty is preferable to being informed that Huntington's disease is the certain prospect; and that 30 years or so of life before onset of Huntington's disease symptoms more than compensates for the years with increasing symptoms and the premature death (Hemphill, 1972; Lynch et al, 1972). In any case whether to learn if one is destined for Huntington's disease or for a normal life must be an excruciating decision (Lynch et al, 1972).

Adoption of children in families with Huntington's disease is often suggested but the practical fact is that adoption agencies may discourage placement in homes where the potential for a disorder such as Huntington's disease in one parent exists (Emery et al, 1973). With advances in sperm banking, another alternative for a man at risk would be to bank his sperm, undergo vasectomy, and await the development of an accurate predictive test.

Thrust of genetic counselling. Opinion differs as to whether genetic counsel should reflect the bias of the counsellor (Emery and Smith, 1970; Fraser, 1971). A similar difference of opinion exists specifically among those engaged in counselling for Huntington's disease (Falek, 1973; Pearson, 1973). As an extreme example of directed counselling, sterilization or other means to prevent reproduction of those affected with Huntington's disease and their children has been advocated as the quickest means to reduce society's burden (Davenport and Muncey, 1916). But such an approach, insensitive to the rights and desires of the individuals involved, would discourage any beside those already so persuaded to come forward. Hence, unless the state was prepared to ascertain and sterilize all known or suspected patients with Huntington's disease, their sibs, and their children, this approach might well have a negative eugenic impact, encouraging silence, and the perpetuation of ignorance.

Enlightment rather than compulsion would seem the proper thrust (Lederberg, 1973) since those in need of counselling seem to prefer a supportive source rather than a threatening or even neutral source. Thus, in this selected population, CCHD, which has as one of its stated purposes the emotional support of Huntington-disease families, was indicated as a more desirable source of information than genetic counsellors and medical specialists.

CCHD as a source of counsel. From our data CCHD appears to be as effective as any source 
including medical geneticists, in conveying the $50 \%$ risk of transmission. Ninety-four percent of those indicating CCHD as their best source of information correctly stated the $50 \%$ transmission risk of this autosomal dominant trait. Admittedly, the concept of autosomal recessive inheritance is more difficult to grasp but less than two-thirds of parents interviewed belonging to a foundation concerned with a disease so inherited could give the correct risk figure (Sibinga and Friedman, 1971; Leonard et al, 1972).

Concern that an organization such as CCHD might, in its desire to provide support, de-emphasize certain physical, psychological, or hereditary aspects of Huntington's disease does not seem warranted. Those indicating CCHD as their best source of information differed little in their attitudes from those listing genetic counsellors or medical specialists. They emphasized mental and psychological changes; were equally aware of the risk of transmission, and were not significantly different in their desire for family limitation.

In Huntington's disease, where so much suffering has resulted from ignorance and the reluctance of those at risk to come forward, an organization designed to overcome just these obstacles can play an important role. Patients and relatives are provided with a means to focus their energies through regular group meetings and a regular newsletter while scientific investigators interested in Huntington's disease, in turn, have access to an organized, generally receptive group for evaluation.

We are indebted to Marjorie Guthrie, Executive Secretary, Committee to Combat Huntington's Disease, New York, New York for collaboration in distributing the questionnaires and to J. H. Ellenberg and S. Z. Edelstein, Office of Biometry, NINDS, National Institutes of Health, Bethesda, Maryland 20014 for construction of the contingency table and performance of tests of significance.

Presented at the American Society of Human Genetics, Atlanta, Georgia, October 1973.

\section{REFERENCES}

Bruyn, G. W. (1968). Huntington's chorea. Historical, clinical and laboratory synopsis. In Handbook of Clinical Neurology, vol. 6, ed. by P. J. Vinken and G. W. Bruyn, pp. 298-378. NorthHolland, Amsterdam.
Carter, C. O., Fraser Roberts, J. A., Evans, K. A., and Buck, A. R. (1971). Genetic clinic: a follow-up. Lancet, 1, 281-285.

Davenport, C. B. and Muncey, E. B. (1916). Huntington's chorea in relation to heredity and eugenics. American fournal of Insanity, 73, 195-222.

Dewhurst, K., Oliver, J. E., and McKnight, A. L. (1970). Sociopsychiatric consequences of Huntington's disease. British fournal of Psychiatry, 116, 255-258.

Emery, A. E. H. and Smith, C. (1970). Ascertainment and prevention of genetic disease. British Medical fournal, 3, 636-637.

Emery, A. E. H., Watt, M. S., and Clack, E. (1973). Social effects of genetic counselling. British Medical fournal, 1, 724-726.

Falek, A. (1973). Issues and ethnics in genetic counseling with Huntington's disease families. The Psychiatric Forum, 4, 51-60.

Fraser, F. C. (1971). Genetic counseling. Hospital Practice, 49-56.

Hecht, F. and Holmes, L. B. (1972). What we don't know about genetic counseling. New England fournal of Medicine, 287, 464465.

Hemphill, M. (1972). Tests for presymptomati Huntington's chorea. New England fournal of Medicine, 287, 823.

Huntington, G. (1872). On chorea. The Medical and Surgical Reporter, 26, 317-321.

Klawans, H. L., Paulson, G. W., Ringel, S. P., and Barbeau, A. (1972). Use of L-DOPA in the detection of presymptomatic Hungtington's chorea. New England fournal of Mcdicine, 286, 1332-1334.

Lappé, M., Gustafson, J. M., and Roblin, R. (1972). Ethical and social issues in screening for genetic disease. New England fournal of Medicine, 286, 1129-1132.

Lederberg, J. (1973). The genetics of human nature. Social Research, 40, 375-406.

Leonard, C. O., Chase, G. A., and Childs, B. (1972). Genetic counseling: a consumers' view. New England fournal of Medicine, 287, 433-439.

Lynch, H. T., Harlan, W. L., and Dyhrberg, J. S. (1972). Subjective perspective of a family with Huntington's chorea: Implications for genetic counseling. Archives of General Psychiatry, 27, 67-72.

McKusick, V. A. (1969). Family-oriented follow-up. fournal of Chronic Diseases, 22, 1-7.

Menkes, J. H. and Stein, N. (1973). Fibroblast cultures in Huntington's disease. New England fournal of Medicine, 288, 856-857.

Murphy, E. A. (1973). Probabilities in genetic counseling. Birth Defects Original Article Series, 9, no. 4, 19-33.

Pearson, J. S. (1973). Family support and counseling in Huntington's disease. The Psychiatric Forum, 4, 46-50.

Reed, T. E. and Neel, J. V. (1959). Huntington's chorea in Michigan. American fournal of Human Genetics, 11, 107-136.

Sibinga, M. S. and Friedman, C. J. (1971). Complexities of parental understanding of phenylketonuria. Pediatrics, 48, 216-224.

Smith, C., Holloway, S., and Emery, A. E. H. (1971). Individuals at risk in families with genetic disease. Fournal of Medical Genetics, 8, 453-459.

Wallace, D. C. and Parker, N. (1973). Huntington's chorea in Queensland: The most recent story. In Adrances in Neurology, vol. 1, pp. 223-236, ed. by A. Barbeau, T. N. Chase, and G. W. Paulson. Raven Press: New York.

Waters, C. O. (1848). Letter on chorea. In Practice of Medicine, by R. Dunglison, 3rd ed., vol. 2, p. 216. Lea and Blanchard: Philadelphia. 